\title{
HIV infection and prevention of mother-to- child transmission in childbearing women: La Romana, Dominican Republic, 2002-2006
}

\author{
José Román-Poueriet, ${ }^{1}$ Aracelis D. Fernandez, ${ }^{2}$ \\ Consuelo M. Beck-Sagué, ${ }^{1}$ René García Szabó, ${ }^{3}$ Fermin Mercedes, ${ }^{3}$ \\ William Duke, ${ }^{4}$ Anny Martinez, ${ }^{3}$ and Stephen Nicholas ${ }^{5,6}$
}

Suggested citation

Román-Poueriet J, Fernandez AD, Beck-Sagué CM, García Szabó R, Mercedes F, Duke W, et al. HIV infection and prevention of mother-to-child transmission in childbearing women: La Romana, Dominican Republic, 2002-2006. Rev Panam Salud Publica. 2009;26(4):315-23.

ABSTRACT Objectives. To strengthen prevention of mother-to-child HIV transmission ( $p M T C T$ ) program implementation in La Romana (LR) province, by estimating HIV prevalence and identifying characteristics associated with HIV infection in parturients.

Methods. Umbilical cord blood samples were collected at seven obstetrical sites where over 95\% of LR's deliveries occur during four phases (pilot, expanded pilot, full study, and pMTCT program monitoring) from 2 August 2002 to 30 September 2006. Results were linked to data abstracted from delivery records.

Results. HIV seroprevalence was 2.6\% (263/10 040 overall; 114/4 452, full-study phase (95\% confidence interval $=2.1 \%-3.1 \%)$ ). Most HIV-infected parturients were Dominican $(68.9 \%)$ and urban (64.0\%). However, prevalence was higher among Haitians $(3.7 \%)$ than Dominicans $(2.3 \%(\mathrm{p}<0.001))$, especially those aged $21-25$ years $(5.2 \%$ vs. $2.3 \%(\mathrm{p}<0.001))$, and among rural, batey, and peri-urban (vs. urban) parturients $(3.4 \%$ vs. $2.3 \%,(\mathrm{p}=0.003))$. HIV prevalence was associated with commercial sex work (reported by only $0.4 \%$ ), and prior pregnancy. In logistic regression analysis, commercial sex work, Haitian nationality, and prior pregnancy were independently associated with HIV infection. Caesarean deliveries were more frequent, and rose in the last years of the study, among HIV seropositives; however, most deliveries among seropositives $(57.5 \%)$ were vaginal.

Conclusions. HIV prevalence among LR parturients was higher than the estimated prevalence in the Dominican Republic $(0.8 \%-1.0 \%)$ and, in contrast to past studies, predominantly affected urban Dominicans. HIV prevalence among LR Haitian parturients was higher than among Dominican counterparts and prenatal clinic attendees in Haiti (who had a rate of $3.1 \%)$. Consistently implemented, targeted pMTCT interventions are needed.

Key words HIV infections; infectious disease transmission, vertical; Dominican Republic.

1 Clínica de Familia MIR, La Romana, Dominican Republic.

2 Department of Pediatrics, Columbia University College of Physicians \& Surgeons, New York, NY, United States of America. Send correspondence and reprint requests to: Aracelis D. Fernandez, Columbia University, Department of Pediatrics, Harlem Hospital Center, 506 Lenox Ave, MLK 16119, New York, NY 10037, United States of America; telephone: +1 (212) 939-4041; fax: +1 (212) 9394050; e-mail adf2118@columbia.edu
Universidad Central del Este, San Pedro de Macorís, Dominican Republic.

4 Dominican Republic Office, Global AIDS Program, U.S. Centers for Disease Control and Prevention, Santo Domingo, Dominican Republic.

5 Columbia University International Family AIDS Program, New York, NY, United States of America.

6 Columbia University Mailman School of Public Health, New York, NY, United States of America.
The Caribbean region, after subSaharan Africa, has the highest HIV prevalence in the world (1). Over $75 \%$ of the region's HIV-infected persons live on the island of Hispaniola, which is shared by Haiti and the Dominican Republic (DR). Since the beginning of the millennium, more than $25 \%$ of this population 
has lived in the DR (2). From the mid1980s onward, HIV infection has been predominantly urban in Haiti but rural in the DR (3); this rural predominance has stood in contrast to most other developing country epidemics (4-7). As elsewhere, migration, along with unemployment and discrimination, contributes to HIV transmission. Many of the estimated 800000 Haitians living in the Dominican Republic, including about 280000 undocumented Dominican-born persons of Haitian descent, are affected by the HIV epidemic $(4,8-10)$.

Lack of reliable HIV surveillance and health care service data in the DR impairs understanding of Hispaniola's epidemic, the effect of transnational and intra-national urban-rural migration, and trends in health care service utilization. While recent assessments conclude that "the number of new HIV infections in the DR is nearly stable" (11), concerns persist that high HIV prevalence and low access to care, related to poverty and discrimination, increase HIV transmission (10). Prevention efforts may be making more headway in Haiti, where antenatal clinic attendee HIV prevalence decreased from $6.2 \%$ (1993; 95\% confidence interval $(\mathrm{CI})=5.9 \%-6.5 \%)$ to $3.1 \%$ $(2004 ; 95 \% \mathrm{CI}=3.0 \%-3.2 \%)(11,12)$.

Since 1999, several partners have collaborated to serve persons with HIV infection in La Romana (LR) province, a major sugar, manufacturing, and tourism industry center in the eastern DR, the region with the highest HIV prevalence in the country (13). The objectives of this study were to improve understanding of HIV infection in LR parturients; strengthen LR's prevention of mother-to-child transmission (pMTCT) program; evaluate use of key services; and assess trends. To these ends, an HIV prevalence survey of childbearing women was conducted in an obstetrical network of public-private facilities where over $95 \%$ of LR deliveries occur.

\section{MATERIALS AND METHODS}

\section{Study setting}

LR has 276000 inhabitants, representing approximately $3.2 \%$ of the DR's 8.75 million population, including 80000 women aged 15 to 50 years $(14,15)$. The capital, La Romana City (the country's third-largest city), has a population of 190 000. As noted in a DR government report to the United Nations (16), accord- ing to a 2000 survey, an estimated 100000 female commercial sex workers (CSWs) work in Santo Domingo and four provinces, including LR; based on authors' estimates, about $4-8 \%$ of these work in LR. Many area sugarcane workers and their families live in 126 rural bateyes (underserved sugarcane plantation communities). Batey residents include Haitian permanent residents, seasonal migrant workers, and indigent Dominicans (4). The province is served by one urban hospital, one rural hospital, and a network of rural clinics administered by the Ministry of Health; a social security hospital; a large private hospital (17); and 18 other facilities. ${ }^{7}$ More than $95 \%$ of deliveries in the province, as throughout the DR, occur in hospitals (18).

The Columbia University International Family AIDS Program (CU-IFAP) has supported HIV/AIDS care, education and training, and programs to improve services for persons living with HIV infection in LR since 1999 (19). CU-IFAP collaborates with the Fundación MIR's Casa de Paz project (20), a local charity, and Complejo Micaeliano, a religious organization that provides social and health services-including a governmentsupported sexually transmitted disease (STD) clinic-to CSWs, and functions as a CSW HIV sentinel surveillance site (21). Universidad Central del Este School of Medicine, which is affiliated with two LR hospitals, is an academic partner.

\section{Study sites and phases}

This report analyzes data from all four phases of this multicenter study. The pilot phase (phase 1) was conducted from 2 August to 31 December 2002 at an obstetrical clinic primarily serving HIVinfected women (specialized HIV clinic), the social security hospital, and two other small private clinics. An expanded pilot phase (phase 2) adding the province's remaining main obstetric facilities was conducted from 1 January to 30 September 2003. Phase 2 included a 105-bed urban public hospital, a 20-bed rural public hospital, the 175-bed social security hospital, and a 72-bed private hospital.

This collaboration involved a publicprivate obstetrical network that in 2000

\footnotetext{
Universidad Central del Este, Public Health Program. Diagnostico de salud provincia, La Romana, año 2000. La Romana (DR): UCE; 2000.
}

was estimated to deliver over $95 \%$ of the province's newborns. Once collection rates were greater than $80 \%$, a full-study phase (phase 3) was conducted at all sites (from 1 October 2003 to 31 December 2004). Study data indicated that in the first three phases $50.0 \%$ of HIVinfected parturients were delivered at the urban public hospital and 35.9\% were delivered at the specialized HIV clinic. The latter institution ceased operations in 2005, and all HIV-infected patients were referred to the urban public hospital. Therefore, the final study phase (phase 4), conducted from 1 January 2005 to 30 September 2006, was limited to the public urban hospital. This phase (quality-of-services monitoring) was intended to assess adherence to national guidelines recommending caesarean delivery for pMTCT. Throughout all study phases, national policies based on Ministry of Health guidelines dictated that outpatient and hospital-based voluntary HIV counseling and testing programs be available at all sites, as described below. The only protocol changes introduced during the study were the addition of study sites and, in 2005, the restriction of the study to one site. No other changes were made to data abstraction or analysis methods in the 50-month study.

\section{Policies for prevention of mother- to-child HIV transmission}

In 2001, the Ministry of Health introduced a national pMTCT program promoting antenatal voluntary counseling and testing, single-dose nevirapine treatment for HIV-infected parturients and their newborns, elective caesarean delivery, and the use of formula as a breastfeeding alternative. LR province's pMTCT program was implemented in the urban public hospital in September 2003, shortly before the full-study phase. In January 2005, the specialized HIV clinic ceased operations and pMTCT patients were referred to the urban public hospital.

\section{Collection of umbilical cord blood specimens}

Umbilical cord blood (UCB) specimens from all live births were collected in sterile, additive-free test tubes by hospital or clinic personnel at deliveries in collaborating centers from Monday through Saturday of each week, includ- 
ing holidays (87.5\% of all days), and assigned a unique study number.

\section{Collection of maternal and infant data}

After completing relevant training, delivery room personnel abstracted demographic, clinical, and pregnancy outcome data from delivery and newborn records, using standard abstraction forms. The information was recorded on the institutions' forms, according to each institution's policies, by their staff. Data not abstracted onto the form by hospital personnel were considered missing; study staff did not examine records to confirm or evaluate data abstraction. No identifier other than the UCB specimen's study number was recorded on the abstraction form. Once the form was completed, any connection between the study number and the parturient or infant identifiers was destroyed. Study personnel collected the UCB specimens and abstraction forms daily, comparing number of births to number of specimens collected, but did not review the records.

\section{UCB tests}

Laboratory staff was blinded to maternal, infant, and delivery characteristics. After their receipt, UCB specimens were centrifuged, and serum was tested for antibody to HIV-1 using an enzymelinked immunoassay (ELISA). If repeatedly positive, the specimens were tested using Western blot. A confirmed positive result was interpreted as indicative of maternal HIV infection and infant perinatal HIV exposure (not necessarily infection).

Serum specimens were also tested for syphilis, using the Venereal Disease Research Laboratory (VDRL) non-treponemal serologic assay, and for hepatitis B surface antigen. Specimens reactive on VDRL testing were tested for confirmation using fluorescent treponemal antibody absorption.

\section{Data analysis}

Study staff entered the abstracted data in a Microsoft Excel spreadsheet and linked the UCB specimen laboratory results through the unique study number. Data from the Excel file were imported and analyzed using Epi Info for Windows 3.43 (Centers for Disease Control and Prevention, Atlanta, Georgia, USA) (22). The strength of associations was estimated using prevalence ratios (PRs); 95\% CIs were used to assess precision of estimated proportions and PRs. Chisquare or Fisher's exact two-tailed test probabilities were used for significance testing. Because of reliance on institutions' medical records, which were often incomplete, there were missing data for many parturients for some variables. Parturients were excluded from analysis of any variables for which they had no data, and the number of parturients included was reported for each variable. Stratified analyses were conducted to control for confounders, and multivariate logistic regression models were constructed to identify factors independently associated with HIV seropositivity (starting with variables plausibly linkable to causation associated with HIV infection in bivariate analysis with a significance level of $p \leq 0.1$ ). A backward stepwise procedure was used to remove predictors with adjusted significance levels of $p>0.1$. The Wald test was used to evaluate differences among variables, and the significance of the model's likelihood-ratio chisquare test was determined $(22,23)$.

\section{Human ethics committee approval}

This study was approved by the Columbia University Institutional Review Board at Harlem Hospital Center; the Committee for Internal Review for Protocols and Investigations, Santo Domingo, DR; and the DR Ministry of Health's Bioethics Committee.

\section{RESULTS}

\section{Collection of UCB specimens}

During the 29 months from 2 August 2002 through 31 December 2004 (study phases 1-3), 8258 infants were born on study days at the seven centers, and 5370 UCB specimens were obtained (Table 1). During the subsequent qualityof-services monitoring phase, from 1 January 2005 through 30 September 2006, 4670 additional UCB specimens were obtained ( $n=10040$ ). UCB HIV-1 sample collection rates were $68.0 \%$ (pilot phase), $35.7 \%$ (pilot expansion phase), $96.4 \%$ (full-study phase), and $69.9 \%$ (qualitymonitoring phase). For births where UCB specimens were not collected, no parturient data were abstracted or available.
For all study phases combined, the proportion of births with UCB specimen collection varied by center (Table 2); for the full-study phase alone, the proportion of births with specimen collection was higher, but still varied across centers. Centers with smaller total numbers of deliveries and lower HIV prevalence tended to contribute lower numbers of specimens.

\section{Maternal population characteristics}

Maternal age at delivery ranged from 12 to 52 years (median $=23$ years; mean $=$ 23.6 years). Most women of known origin were Dominican (7 718, or $78.1 \%$ ) or Haitian (2 163, or $21.9 \%)$. The majority of deliveries took place at the urban public hospital $(75.6 \%)$ or the social security hospital $(11.7 \%)$ (Table 2). The qualityof-services monitoring phase was confined to the urban public hospital. Antenatal care was reported for 9479 out of 9748 (97.2\%) newborns. The overall proportion of births delivered by caesarean was 1972 out of 9945 (19.6\%), and 8692 out of 9733 newborns (89.3\%) had undergone a previous HIV serologic test.

\section{HIV prevalence}

Overall HIV prevalence was 2.6\% (263 out of 10040$)$ ( $95 \% \mathrm{CI}=2.3 \%-3.0 \%$ ); during the 15-month full-study phase, prevalence was also $2.6 \%(95 \% \mathrm{CI}=2.1 \%$ $3.1 \%$ ) (Table 1). Seroprevalence varied by center, from $0.0 \%$ in a small private center to $69.1 \%$ in the specialized HIV clinic. Although the specialized clinic had the highest HIV prevalence, most HIV-infected women delivered in the urban public hospital. Most HIVinfected parturients were Dominican and lived in urban areas (68.9 and 64.0\% respectively); however, Haitian and nonurban residents were more likely than Dominican and urban residents to be infected (3.7\% vs. $2.3 \%$, and $3.4 \%$ vs. $2.3 \%$, respectively) (Table 3 ). Women with HIV infection were between 15 and 41 years old, and women aged less than 21 years had lower HIV prevalence than other age groups combined (Table 3 ). Seroprevalence varied significantly by age group $(2.0 \%$ in women less than 21 years old, $2.8 \%$ in $21-25$ year olds, $3.1 \%$ in 26-30 year olds, and $2.8 \%$ in those over 30 years old). When age group was stratified by nationality, HIV prevalence was higher among Haitians than among 
TABLE 1. Number and proportion of births in which an umbilical cord blood (UCB) specimen was collected, proportion collected during study days, and number and proportion of HIV-positive specimens, by phase of study on HIV prevalence and pMTCTa program implementation, La Romana, Dominican Republic, 2002-2006

\begin{tabular}{|c|c|c|c|c|c|c|}
\hline Study phase (duration) & $\begin{array}{c}\text { Total } \\
\text { No. of } \\
\text { deliveries } \\
\text { (live births) }^{\mathrm{b}}\end{array}$ & $\begin{array}{c}\text { No. }(\%) \text { of } \\
\text { deliveries } \\
\text { with UCB } \\
\text { sample }^{c}\end{array}$ & $\begin{array}{c}\text { \% UCB } \\
\text { samples } \\
\text { collected } \\
\text { on study } \\
\text { days }^{\mathrm{d}}\end{array}$ & Centere & $\begin{array}{l}\text { No. of } \\
\text { HIV-positive } \\
\text { UCB } \\
\text { samples }\end{array}$ & $\begin{array}{c}\text { HIV } \\
\text { seroprevalence } \\
\left(95 \% \mathrm{Cl}^{f}\right)\end{array}$ \\
\hline $\begin{array}{l}\text { 1. Pilot phase } \\
\text { (2 August-31 December 2002) }\end{array}$ & 142 & $\begin{array}{c}83 \\
(58.4)\end{array}$ & 68.0 & $1,3,4$ & 12 & $\begin{array}{c}14.5 \% \\
(7.7-23.9 \%)\end{array}$ \\
\hline $\begin{array}{l}\text { 2. Pilot expansion phase } \\
\text { ( } 1 \text { January-30 September 2003) }\end{array}$ & 2729 & $\begin{array}{c}835 \\
(30.6)\end{array}$ & 35.7 & $1-7$ & 30 & $\begin{array}{c}3.6 \% \\
(2.5-5.2 \%)\end{array}$ \\
\hline Subtotal & 8258 & $\begin{array}{l}5370 \\
(65.0)\end{array}$ & 75.8 & $1-7$ & 156 & $\begin{array}{c}2.9 \% \\
(2.5-3.4 \%)\end{array}$ \\
\hline $\begin{array}{l}\text { 4. pMTCT program monitoring phase } \\
\text { (1 January 2005-30 September 2006) }\end{array}$ & 7797 & $\begin{array}{r}4670 \\
(59.9)\end{array}$ & 69.9 & 5 & 107 & $\begin{array}{c}2.3 \% \\
(1.9-2.8 \%)\end{array}$ \\
\hline Total & 16055 & $\begin{array}{r}10040 \\
(62.5)\end{array}$ & 72.9 & $1-7$ & 263 & $\begin{array}{c}2.6 \% \\
(2.3-3.0 \%)\end{array}$ \\
\hline
\end{tabular}

a pMTCT $=$ prevention of mother-to-child transmission.

b Total number of births in participating center(s) during study phase (including Sundays).

${ }^{c}$ Number and proportion of births in which a UCB sample was collected (number of UCB specimens collected/total number of births in participating center(s) during study phase (including Sundays) $x$ 100).

d Proportion of births in which a UCB sample was collected during study days (i.e., Monday through Saturday, including holidays, or $85.7 \%$ of days) (number of UCB specimens collected/total number of births in participating center(s) during study phase (including Sundays) x 100/0.857).

e Participating obstetric center: 1, specialized HIV clinic; 2, private clinic 1; 3, private clinic $2 ; 4$, social security hospital; 5, public hospital (urban); 6 , private hospital; 7, public hospital (rural).

f $95 \%$ confidence interval.

TABLE 2. Total number of deliveries, proportion with umbilical cord blood (UCB) specimen collection (for all study phases, and 15-month full-study phase), and HIV seroprevalence, by center where delivery occurred, HIV prevalence/ pMTCT ${ }^{a}$ program implementation study. La Romana, Dominican Republic, August 2002-September 2006

\begin{tabular}{|c|c|c|c|c|}
\hline Center & $\begin{array}{c}\text { Total } \\
\text { No. of } \\
\text { deliveries } \\
\text { (live births) }^{\mathrm{b}}\end{array}$ & $\begin{array}{l}\text { No. (\%) of } \\
\text { of deliveries } \\
\text { with UCB } \\
\text { sample }^{c}\end{array}$ & $\begin{array}{l}\text { No. of deliveries } \\
\text { in full-study } \\
\text { phase (\% with } \\
\text { UCB sample) })^{d}\end{array}$ & $\begin{array}{c}\text { Number }(\%) \text { of } \\
\text { HIV infections } \\
{\left[95 \% \mathrm{Cl}^{\mathrm{f}}\right]}\end{array}$ \\
\hline 1. Specialized HIV clinic & 85 & $81(95.3)$ & $41(97.6)$ & $\begin{array}{c}56(69.1) \\
{[57.9-78.9]}\end{array}$ \\
\hline 2. Private clinic 1 & 257 & $57(22.2)$ & $28(21.1)$ & $\begin{array}{c}1(1.8) \\
{[0-9.4]}\end{array}$ \\
\hline 3. Private clinic 2 & 107 & $47(43.9)$ & $46(43.5)$ & $\begin{array}{c}0 \\
{[0-6.3]}\end{array}$ \\
\hline 4. Social security hospital & 1612 & $1106(68.6)$ & $932(78.6)$ & $\begin{array}{c}13(1.2) \\
{[0.7-2.1]}\end{array}$ \\
\hline 5. Public hospital, urban & 10452 & $7753(74.2)$ & $3426(87.6)$ & $\begin{array}{l}180(2.3) \\
{[2.0-2.7]}\end{array}$ \\
\hline 6. Private hospital & 614 & $483(78.7)$ & $523(83.0)$ & $\begin{array}{c}3(0.6) \\
{[0.2-2.0]}\end{array}$ \\
\hline 7. Public hospital, rural & 692 & $513(74.1)$ & $293(67.5)$ & $\begin{array}{l}10(1.9) \\
{[1.0-3.7]}\end{array}$ \\
\hline Total & 13819 & $10040(72.7)$ & $5389(82.6)$ & $\begin{array}{l}263(2.6) \\
{[2.3-3.0]}\end{array}$ \\
\hline \multicolumn{5}{|c|}{$\begin{array}{l}\text { a pMTCT = prevention of mother-to-child transmission. } \\
\text { b Total number of deliveries for all study phases combined (including Sundays). } \\
\text { c Number of deliveries (and proportion of total deliveries) with collection of UCB sample for all study phases combined (including Sundays). } \\
\text { d Number of deliveries during the full-study phase (including Sundays), and proportion of those with UCB sample collection. Proportions of deliveries } \\
\text { during study days (i.e., excluding Sundays) with UCB sample collection, by center, are as follows: Center 1,97.6\%; Center } 2,24.5 \% \text {; Center } 3 \text {, } \\
50.0 \% \text {; Center } 4,91.7 \% \text {; Center } 5,98.8 \% \text {; Center } 6,96.9 \% \text {; Center } 7,78.8 \% \text {. } \\
\text { e Number and proportion of UCB samples collected from participating center(s) that tested positive for the HIV antibody. } \\
\text { f } 95 \% \text { confidence interval. }\end{array}$} \\
\hline
\end{tabular}

Dominicans aged less than 21 years $(2.9 \%$ vs. $1.7 \% ; p=0.037)$ and $21-25$ years (5.2\% vs. $2.3 \% ; p<0.001)$, but did not differ significantly by origin in women more than 25 years old (data not shown).
HIV prevalence was higher among women who had past pregnancies and abortions versus those who did not (Table 3), and in those with CSW documentation in their records (only $0.4 \%$ of study participants). HIV infection was associated with tuberculosis (current or past), blood transfusions, and a history of STDs. HIV prevalence varied by VDRL reactivity, but this difference was 
TABLE 3. Maternal population, pregnancy, delivery, and birth outcome characteristics associated with HIV infection among parturients $(n=10040)$, La Romana, Dominican Republic, August 2002 September $2006^{a}$

\begin{tabular}{|c|c|c|c|c|}
\hline Variable & $\begin{array}{c}\text { No. of HIV- } \\
\text { infected/total } \\
\text { No. of parturients } \\
\text { per variable }(\%)\end{array}$ & $\begin{array}{l}\text { Total No. of } \\
\text { parturients } \\
\text { per category }\end{array}$ & $\begin{array}{c}\mathrm{PR}^{\mathrm{c}} \\
\left(95 \% \mathrm{Cl}^{\mathrm{d}}\right)\end{array}$ & $P$-value \\
\hline \multicolumn{5}{|l|}{ Maternal population characteristics } \\
\hline \multicolumn{5}{|l|}{ Origin } \\
\hline Haiti & $80 / 2163(3.7)$ & & 1.6 & \\
\hline Dominican Republic, other $\left(\mathrm{R}^{\mathrm{e}}\right)$ & $177 / 7718(2.3)$ & 9881 & $(1.2-2.1)$ & $<0.001$ \\
\hline \multicolumn{5}{|l|}{ Age at delivery } \\
\hline$\geq 21$ years & $193 / 6670(2.9)$ & & 1.5 & \\
\hline$<21$ years $(R)$ & 65/3 $269(2.0)$ & 9939 & $(1.1-1.9)$ & 0.008 \\
\hline \multicolumn{5}{|l|}{$>1$ past pregnancy } \\
\hline Yes & $211 / 7052(3.0)$ & & 1.7 & \\
\hline No $(R)$ & $52 / 2988(1.7)$ & 10040 & $(1.3-2.3)$ & $<0.001$ \\
\hline \multicolumn{5}{|l|}{ Past abortion } \\
\hline Yes & 73/1 $708(4.3)$ & & 1.9 & \\
\hline No $(R)$ & 190/8 $332(2.3)$ & 10040 & $(1.4-2.4)$ & $<0.001$ \\
\hline \multicolumn{5}{|l|}{ Commercial sex worker ${ }^{f}$} \\
\hline Yes & $6 / 33(18.2)$ & & 6.7 & \\
\hline No $(\mathrm{R})$ & $234 / 8528(2.7)$ & 8561 & $(3.2-13.9)$ & $<0.001^{\mathrm{g}}$ \\
\hline \multicolumn{5}{|l|}{$\begin{array}{l}\text { Non-urban (i.e., rural, batey, } \\
\text { or peri-urban resident) }\end{array}$} \\
\hline Yes & 91/2 $708(3.4)$ & & 1.5 & \\
\hline No (urban) (R) & $162 / 7039(2.3)$ & 9747 & $(1.1-1.9)$ & 0.003 \\
\hline \multicolumn{5}{|l|}{ Reactive VDRL' ${ }^{i}$} \\
\hline Yes & $3 / 36(8.3)$ & & 3.2 & \\
\hline No (R) & $95 / 3600(2.6)$ & 3636 & $(1.0-9.5)$ & $0.07^{9}$ \\
\hline \multicolumn{5}{|l|}{ Transfusion } \\
\hline Yes & 11/117 (9.4) & & 3.5 & \\
\hline No $(R)$ & 230/8 $636(2.7)$ & 8753 & $(2.0-6.3)$ & $<0.001^{9}$ \\
\hline \multicolumn{5}{|l|}{ Tuberculosis (current or past) } \\
\hline Yes & $4 / 50(8.0)$ & & 2.9 & \\
\hline No $(R)$ & $238 / 8644(2.8)$ & 8694 & $(1.1-7.5)$ & $0.09 \mathrm{~g}$ \\
\hline \multicolumn{5}{|c|}{$\begin{array}{l}\text { Pregnancy, delivery, and birth outcome } \\
\text { characteristics }\end{array}$} \\
\hline \multicolumn{5}{|l|}{ Pregnancy-related hypertension } \\
\hline Yes & 7/52 (13.5) & & 5.1 & \\
\hline No $(\mathrm{R})$ & 245/9 $203(2.7)$ & 9255 & $(2.5-10.2)$ & $<0.001^{g}$ \\
\hline \multicolumn{5}{|l|}{ Caesarean delivery } \\
\hline Yes & 110/1 $972(5.6)$ & & 3.0 & \\
\hline No (vaginal) (R) & 149/7 $973(1.9)$ & 9945 & $(2.3-3.8)$ & $<0.001$ \\
\hline \multicolumn{5}{|l|}{ Birth weight } \\
\hline$<2500 \mathrm{~g}$ & $32 / 680(4.7)$ & & 1.9 & \\
\hline$\geq 2500 \mathrm{~g}(\mathrm{R})$ & $231 / 9359(2.5)$ & 10039 & $(1.3-2.7)$ & $<0.001$ \\
\hline
\end{tabular}

a The variables for pregnancy, delivery, and birth outcome, and current or past tuberculosis, are more likely to be effects of, or to have followed, HIV infection than to have preceded HIV infection or to have any risk implications.

${ }^{b}$ Categories may not sum to 10040 due to missing data; number of parturients includes only those with data for the respective variable.

c Prevalence ratio.

d $95 \%$ confidence interval.

${ }^{e}$ Reference value.

f Documentation of commercial sex work in antenatal or delivery record.

${ }^{g}$ Fisher's exact two-tailed test.

${ }^{\mathrm{h}}$ Underserved sugarcane plantation community.

' Venereal Disease Research Laboratory test (non-treponemal).

not significant. Drug use was not significantly associated with HIV infection, and HIV prevalence in the urban public hospital varied by year between 2.1 and $2.5 \%(p=0.7)$; the increase in the number of HIV-infected women after the specialized HIV clinic discontinued its services in 2005 was offset by a marked increase in total number of deliveries and UCB collections at the urban public hospital (data not shown).

\section{Pregnancy, delivery, and birth outcome characteristics}

Virtually all parturients reported antenatal care, which did not vary by HIV status. In general, seropositive parturi- ents were not more likely to develop pregnancy-related complications. However, hypertensive complications and delivery of a low-birth-weight infant were associated with HIV maternal seropositivity (Table 3); 32 out of 263 infants born to seropositive parturients (12.2\%) weighed less than $2500 \mathrm{~g}$ (vs. $6.6 \%$ of those born to seronegatives).

\section{Caesarean delivery for pMTCT}

For all study phases combined, compared to seronegative women, HIVseropositive women more often had caesarean delivery, although the majority $(57.5 \%)$ delivered vaginally (Table 3 ). Fifty-three out of 110 (48.2\%) of the caesarian deliveries for pMTCT occurred in the specialized HIV clinic. In 20032004 , only 12 out of 78 (15.4\%) deliveries in seropositive women in the urban public hospital were by caesarian, less than in seronegatives (581 out of 3260 , or $17.8 \%$ ), despite national pMTCT guidelines. The proportion of women with HIV infection delivered by caesarean rose to $34.8 \%$ in 2005 , and to $50 \%$ in $2006(p=0.001)$, when seropositive women were significantly more likely than seronegatives to deliver by caesarean (39 out of 99 , or $39.4 \%$, vs. 791 out of 4235 , or $18.7 \%$; $p<0.001$ ).

Seropositive Haitians were less likely to deliver by caesarean $(33.8 \%)$ than seropositive Dominicans (46.6\%; $p=0.054$ ). However, the caesarean delivery rate was so low among uninfected Haitians (11.2\% vs. $21.1 \%$ in Dominicans; $p<0.001)$ that the increase in caesareans associated with HIV in Haitians (over 3.0-fold; $p<0.001$ ) was higher than among Dominicans (2.2fold; $p<0.001$ ). Both the proportion of HIV-infected parturients who delivered by caesarean and the proportion of Haitians varied by site $(28.8 \%-100 \%$ and $0-57.9 \%$, respectively) (data not shown).

\section{Multivariate analysis of maternal factors associated with HIV infection}

Haitian origin was not associated with VDRL reactivity, documentation as a CSW, or past abortion. When controlled for these factors, the strength of the association between Haitian origin and HIV infection was unchanged. When controlled for prior pregnancies, it decreased slightly. When documentation of commercial sex work, origin, past pregnancies, and non-urban residence were 
TABLE 4. Multivariate logistic regression analysis of characteristics associated with HIV infection in childbearing women $\left(n=8388^{\mathrm{a}}\right)$, La Romana, Dominican Republic, August 2002-September 2006 ${ }^{\text {b }}$

\begin{tabular}{lccr}
\hline \multicolumn{1}{c}{ Variable } & Odds ratio & $95 \% \mathrm{Cl}^{\mathrm{c}}$ & $P$-value \\
\hline Commercial sex worker $^{\mathrm{d}}$ & 8.0 & $3.2-19.7$ & $<0.0001$ \\
Haitian $^{\mathrm{e}}$ & 1.6 & $1.2-2.2$ & 0.0011 \\
$>1$ past pregnancy $^{\prime}$ & 1.7 & $1.2-2.4$ & 0.0011 \\
Urban $^{f}$ & 0.8 & $0.6-1.0$ & 0.0849 \\
Constant & $\mathrm{NA}^{\mathrm{g}}$ & $\mathrm{NA}$ & $<0.0001$ \\
\hline
\end{tabular}

a Multivariate analysis was restricted to the 8388 parturients who provided data for the five original mode variables: documentation of commercial sex work; $>1$ past pregnancy; maternal age $\geq 21$; Haitian national origin; urban vs. batey (underserved sugarcane plantation community), rural, or peri-urban residence.

${ }^{b}$ Final $-2^{*} \log$-likelihood $=2087.6$; Wald test statistic $=57.9(p=<0.001)$; likelihood ratio test statistic: 41.7 $(p<0.001)$.

${ }^{c}$ Confidence interval.

d Documentation of commercial sex work in antenatal or delivery record.

e Haitian origin.

${ }^{f}$ Resident of urban area (vs. batey, rural area, or peri-urban area).

${ }^{g} \mathrm{NA}=$ not applicable.

analyzed with logistic regression, the model with best fit showed that all variables except non-urban residence were significantly and independently associated with HIV infection (Table 4). Having a non-urban residence was associated with HIV infection if origin was not in the model, suggesting that most of the risk associated with non-urban residence was due to the higher likelihood of Haitians living in non-urban areas versus Dominicans (61.6 vs. $27.8 \%$ respectively; $p<0.001)$.

\section{DISCUSSION}

HIV prevalence was $2.6 \%$ in parturients delivering at seven centers during the 15-month full-study phase during 2003-2004. This was more than three times the DR's estimated adult HIV prevalence in the Demographic Health Survey (DHS) for 2007 (0.8\%-1.0\%) (24), and almost $50 \%$ higher than HIV prevalence in gravidas in Santo Domingo in 2003 (13). The observed prevalence among LR Haitians (3.7\%) was slightly higher than antenatal HIV prevalence in Haiti (3.1\%) in 2004 (12). However, it should be noted that 1) the HIV prevalence observed in this study was similar to that reported in a DR multicenter antenatal clinic HIV prevalence study conducted in 2000-2001 (2.5\%), in which prevalence by site varied from $0.3 \%$ to $4.9 \%$ (25); 2) HIV prevalence in the eastern region of the DR according to the DHS (1.2\%) was $50 \%$ higher than na- tional prevalence; and 3) HIV prevalence estimates from population-based studies tend to be lower than those from antenatal clinic surveys $(24,26)$. The prevalence observed in this study, though high, is also well within the range of 2004 DR antenatal sentinel surveillance estimates (3).

Though HIV prevalence in LR Haitian parturients was higher than mean antenatal clinic HIV prevalence in Haiti and LR Dominican parturients, most HIVinfected women were urban Dominicans, suggesting that the rural-predominant pattern of the DR HIV/AIDS epidemic, observed since the mid-1980s, may no longer characterize the LR epidemic. Although the precision of the estimate for all phases of the 2002-2006 study combined is slightly higher than the estimate for the 15-month full-study phase, both estimates are identical (2.6\%); the wider 95\% CI for the single-phase estimate is entirely due to the smaller number of parturients participating in the full-study phase. HIV prevalence in the urban public hospital did not change significantly over the 50 months of the study.

The fact that more than $60 \%$ of infected Haitians participating in the study lived in rural areas indicates an urgent need for specific focus of HIV prevention efforts in bateyes-a long-standing unaddressed need (4). The finding that HIV rates among LR Haitians are higher than the median antenatal HIV prevalence in Haiti may indicate that they are not benefiting from HIV prevention strategies in
Haiti or the DR. Discrimination and health care disparities affecting Haitian migrants are historical, tenacious problems in the DR. These factors provide a compelling argument for attention to the transnational dynamics of Hispaniola's HIV epidemic, and for improved services in the east. The findings of this study contrast with prevalence in Santo Domingo gravidas aged 15-24 years, which declined from 3\% (1995) to less than $1 \%$ (2003) (1); this decline coincided with the implementation of government prevention programs, including $\mathrm{pMTCT}$ programs, in the year 2000, which were not expanded to LR province until years later.

The highest prevalence of HIV was found in parturients with documentation of commercial sex work in their records, but prevalence was also high in nonprimigravidas, consistent with risk associated with sexual activity. HIV was also more prevalent in women with a history of tuberculosis, which is not surprising given the relationship between HIV and tuberculosis and the fact that tuberculosis incidence in the DR is among the highest in Latin America and the Caribbean (27). The association between HIV and blood transfusion might be due to HIV-associated anemia, which is often severe enough to require transfusion. However, lack of a provincial blood bank, and frequent use of paid donors, which is common in the Caribbean (28), suggests possible transfusion-related $\mathrm{HIV}$ infection. No evidence of an impor- 
tant role for drug use was found, but underreporting is likely.

Hypertensive complications were more frequent in HIV-infected parturients. Although prior studies have suggested that women with untreated HIV infection may be at lower risk of pregnancyrelated hypertension, conflicting findings have emerged $(29,30)$. Preeclampsia among HIV-infected women was associated with highly active antiretroviral therapy duration (31). However, the unavailability of antiretrovirals in LR before mid-2004 makes it doubtful that antiretrovirals explain the association. The observation that multivitamins reduce preeclampsia among HIV-infected women suggests that vitamin deficiency may be an explanation (32). The association between maternal HIV and low birth weight has been previously reported (33).

\section{Limitations}

This study has several limitations. For example, no phase of the study included $100 \%$ of LR deliveries. Although the proportion of births captured during the fullstudy phase exceeded 95\%, the design of the study systematically excluded Sunday births (more than $14 \%$ of total births). The possibility that women with HIV infection were purposely scheduled for weekday appointments because certain procedures (e.g., elective caesareans) were performed mainly Monday through Friday may have increased HIV prevalence during weekdays, and decreased it on Sundays, inflating the study's HIV prevalence estimate. The very low rate of caesarean delivery in women with HIV infection suggests that this was not a factor, but it remains possible.

In addition, both enrollment and seroprevalence varied by center. During the full-study phase, the proportion of births captured among centers with large numbers of deliveries was high. Low enrollment rates in centers with small numbers of deliveries may be unlikely to affect seroprevalence overall, but the concern is somewhat higher with regard to the rural hospital. Variation in enrollment by center is a major limitation of the study and a source of potential bias.

Another limitation was the reliance on data abstracted from medical records, which reduced the reliability of several variables. The low number of women who reported being CSWs in a province with a large CSW population suggests underreporting; although sex work is legal, it is highly unlikely that antenatal records would be reliable in reporting it, or that women would report it to delivery staff as readily as in a confidential survey (16). The fact that STD history data were not reported in almost 900 births reduces the precision of estimates of association between STDs and HIV. Lack of information on births in which UCB specimens were not collected prevents characterization of those mother-infant dyads, though their number was small.

In addition, although data from this study are useful in estimating HIV prevalence in childbearing women, like all HIV prevalence estimates from antenatal and childbearing populations, its representativeness relative to the general adult population is likely to be limited at best (26). In this study, the population with higher fertility also has a higher HIV prevalence, making it even less appropriate to generalize these findings to the general population. Therefore, the prevalence estimate from this study clearly can be used appropriately only for the purpose for which it was designed: to estimate HIV prevalence in childbearing women, and prevalence of exposure to HIV by MTCT among infants in LR province.

Other limitations of the study are related to data collection. Because data were collected without patient identifiers, there was no way to confirm their accuracy, which could have been affected by several factors. For example, staff may have felt compelled to exaggerate compliance with testing guidelines, or report past testing without documentation. In addition, some women may have delivered more than once during 2002-2006, and prevalence among those women may have differed from those who did not (it should be noted, however, that HIV prevalence for the 2002-2006 15month full-study phase did not differ from estimated prevalence for all phases combined). Finally, there may have been a tendency to report Dominican women with darker complexions as "Haitian"; if HIV risk differed by origin, this bias would have tended to reduce the risk associated with Haitian status.

Despite these caveats, this study's strengths include its size (by far the largest of all HIV prevalence studies performed in Caribbean women), which increased its power, and the precision of its estimates; its high enrollment rate; its venue, in which more than $95 \%$ of women deliver in hospitals (18); and its inclusion of health care sites representing a wide spectrum of provincial health services.

\section{Conclusions}

In the past two years, Hispaniola has made strides in addressing the HIV/ AIDS epidemic. However, the DR's eastern region was one of the last to integrate pMTCT in the public sector; despite progress, ongoing challenges include failure to consistently use caesarean delivery for pMTCT, which can decrease MTCT by up to $85 \%$ (34). In 2004, national pMTCT staff has concluded that some centers had refused caesarean deliveries to seropositive women due to concerns about occupational risk (35) and, as observed in the study, caesarean delivery increased among seropositive women in the following years. HIV risk in childbearing Haitians living in LR province appears higher than among those living in their own, higher-prevalence country, suggesting that LR Haitians' risk may relate not only to Haiti's prevalence but also to risks-restricted access to prevention, or other factors-in the DR (4).

In part as a result of this study, recent measures instituted in LR include confidential voluntary counseling and rapid testing by Kreyol (Haitian Creole) speakers in bateyes, and in public emergency, antenatal, delivery, and postpartum health service units. In addition, comprehensive HIV care and treatment programs (including economic support) targeting underserved HIV-infected Haitians have been implemented in the eastern region of the $\mathrm{DR}$, increasing the overall proportion of Haitian parturients in the DR who receive pMTCT services.

Acknowledgments. The authors thank the following people for their support: Lian Fanjul, Lyanne Azqueta, and Manuel Rodríguez (Fundación MIR); Woo Young Shin; Ellen Koenig; José E. Hazim Frappier; José A. Hazim Torres; and Edwin Cubbinson. This study was generously supported in part by the Pincus Family Foundation, the Sy Syms Foundation, and the Honickman Foundation. 


\section{REFERENCES}

1. Joint United Nations Programme on HIV/ AIDS. Uniting the world against AIDS. 06. Fact sheet. Caribbean. Geneva: UNAIDS; 2006 [cited 2008 Jun 10]. Available from: http:// data.unaids.org/pub/GlobalReport/2006/ 200605-FS_Caribbean_en.pdf.

2. Caribbean Epidemiology Center; Pan American Health Organization; World Health Organization. The Caribbean HIV/AIDS epidemic and the situation in member countries of the Caribbean Epidemiology Centre (CAREC). Port of Spain (TT): CAREC/PAHO/WHO; 2007 [cited 2008 Jun 10]. Available from: www.carec.org/documents/Caribbean_HIV Epidemic.pdf.

3. Joint United Nations Programme on HIV/ AIDS. Epidemiological fact sheets on HIV/ AIDS and sexually transmitted infections. Dominican Republic. 2006 update. Geneva: UNAIDS; 2006 [cited 2008 Jun 10]. Available from: www.who.int/globalatlas/predefined Reports/EFS2006/EFS_PDFs/EFS2006_DO. pdf.

4. Brewer TH, Hasbun J, Ryan CA, Hawes SE, Martinez S, Sanchez J, et al. Migration, ethnicity and environment: HIV risk factors for women on the sugar cane plantations of the Dominican Republic. AIDS. 1998;12(14):1879-87.

5. Zuma K, Lurie MN, Williams BG, MkayaMwamburi D, Garnett GP, Sturm AW. Risk factors of sexually transmitted infections among migrant and non-migrant sexual partnerships from rural South Africa. Epidemiol Infect. 2005;133(3):421-8.

6. Serwadda D, Wawer MJ, Musgrave SD, Sewankambo NK, Kaplan JE, Gray RH. HIV risk factors in three geographic strata of rural Rakai District, Uganda. AIDS. 1992;6(9):983-9.

7. Quinn TC. Population migration and the spread of types 1 and 2 human immunodeficiency viruses. Proc Natl Acad Sci USA. 1994; 91(7):2407-14

8. Koenig RE, Pittaluga J, Bogart M, Castro M, Nunez F, Vilorio I, et al. Prevalence of antibodies to the human immunodeficiency virus in Dominicans and Haitians in the Dominican Republic. JAMA. 1987;257(5):631-4.

9. United Nations Office of the High Commissioner for Human Rights. Committee on the Elimination of Racial Discrimination 2008 review of the Dominican Republic. New York: OHCHR; 2008 [cited 2008 Feb 12]. Available from: www2.ohchr.org/english/bodies/cerd/ docs/ngos/HRAdvocates.doc.

10. Cohen J. HIV/AIDS: Latin America \& Caribbean. Dominican Republic: a sour taste on the sugar plantations. Science. 2006;313(5786): 473-5.

11. United States Agency for International Development, Bureau for Global Health. Country profile: HIV/AIDS, Dominican Republic 2004. Brief. Washington: USAID; 2004 [cited 2009 Aug 28]. Available from http://www. usaid.gov/our_work/global health/aids/ Countries/lac/domrepbrief.pdf.

12. Gaillard EM, Boulos LM, André Cayemittes MP, Eustache L, Van Onacker JD, Duval N, et al. Understanding the reasons for decline of HIV prevalence in Haiti. Sex Transm Infect. 2006;82(Suppl 1):i14-20.
13. Monitoring the AIDS Pandemic. HIV infection and AIDS in the Americas: lessons and challenges for the future. Provisional report MAP/EpiNet. Havana: MAP/Epidemiology Network for HIV/AIDS in Latin America and the Caribbean; 2003 [cited 2008 Feb 19]. Available from: www.mapnetwork.org/MAPLAC DraftApril9.2003\%20to\%20print.doc.

14. Horsbrugh M. Dominican Republic. In: International Chamber of Commerce, editor. Americas review 2003/04: the economic and business report. 21st ed. London: Kogan Page; 2003. p. 241-6.

15. United Nations Public Administration Network. E-government readiness in the Caribbean-selected indicators of basic country data. Vol. 1. New York: UNPAN; 2004 [cited 2008 Feb 19]. Available from: http://unpan1. un.org/intradoc/groups/public/documents/ un/unpan017454.pdf.

16. United Nations Committee on the Elimination of Discrimination Against Women. Consideration of reports submitted by States parties under article 18 of the Convention on the Elimination of All Forms of Discrimination against Women. Fifth periodic report of States parties: Dominican Republic. New York: UN CEDAW; 2003 [cited 2009 Feb 19]. Available from: http://daccess-ods.un.org/TMP/ 4454318.html.

17. Secretaría de Estado de Salud Publica y Asistencia Social (DR) [Internet]. Santo Domingo: SESPAS; c2009 [cited 2009 Mar 23]. Centros Habilitados. Servicios. Región V: La Romana; [1 screen]. Available from: www.sespas.gov. do/habilitacion/resultadosProvincia.asp? PROVINCIA=LA\%20ROMANA

18. Fort AL, Kothari MT, Abderrahim N. Postpartum care: levels and determinants in developing countries. DHS Comparative Reports 15. Calverton (MD): Macro International; 2006 [cited 2009 Feb 19]. Available from: http:// pdf.usaid.gov/pdf_docs/PNADJ323.pdf.

19. Familyaids.org [Internet]. New York: Columbia University International Family AIDS Program; c2009 [cited 2009 Feb 19]. Available from: http://www.familyaids.org.

20. Mission International Rescue [Internet]. West Palm Beach (FL): MIR; c2009 [cited 2009 Feb 19]. Projects. Casa de Paz; [1 screen]. Available from: http://www.mirinternational. org $/$ index.php?option=com_content\&view= article\&id $=57 \&$ Itemid $=65$.

21. Joint United Nations Programme on HIV/ AIDS. Epidemiological fact sheets on HIV/ AIDS and sexually transmitted infections. Dominican Republic. 2004 update. Geneva: UNAIDS; 2004 [cited 2009 Feb 19]. Available from: http://data.unaids.org/Publications/ Fact-Sheets01/dominicanrepublic_EN.pdf.

22. Dean AG, Arner TG, Sangam S, Coulombier D, Burton AH, Brendel KA, et al. Epi Info 2000, a database and statistics program for public health professionals for use on Windows 95, 98, NT and 2000 computers. Atlanta (GA): Centers for Disease Control and Prevention; 2000.

23. Kleinbaum DG. Statistics in the health sciences: logistic regression. New York: Springer-Verlag; 1994.
24. Centro de Estudios Sociales y Demográficos; Macro International Inc. Encuesta Demográfica y de Salud 2007. Republica Dominicana. Santo Domingo (DR): CESDEM/Macro International Inc.; 2008 [cited 2009 Feb 19]. Available from: www.cesdem.com $/ \mathrm{html} /$ body publicaciones.html\#endesa2007final.

25. Perez-Then E, Peña R, Tavarez-Rojas M, Peña C, Quiñonez S, Buttler M, et al. Preventing mother-to-child HIV transmission in a developing country: the Dominican Republic experience. J Acquir Immune Defic Syndr. 2003; 34(5):506-11.

26. Gouws E, Mishra V, Fowler TB. Comparison of adult HIV prevalence from national population-based surveys and antenatal clinic surveillance in countries with generalised epidemics: implications for calibrating surveillance data. Sex Transm Infect. 2008;84(Suppl 1):i17-23.

27. World Health Organization. Global tuberculosis control-surveillance, planning, financing. Geneva: WHO; 2008 [cited 2009 Feb 19]. Available from: http://www.who.int/tb/ publications/global_report/2008/chapter_1/ en/index3.html.

28. Gutiérrez MG, de Tejada ES, Cruz JR. A study of sociocultural factors related to voluntary blood donation in the Americas. Rev Panam Salud Publica. 2003;13(2-3):85-90.

29. Wimalasundera RC, Larbalestier N, Smith JH, de Ruiter A, McG Thom SA, Hughes AD, et al. Pre-eclampsia, antiretroviral therapy, and immune reconstitution. Lancet. 2002;360(9340): $1152-4$.

30. Frank KA, Buchmann EJ, Schackis RC. Does human immunodeficiency virus infection protect against preeclampsia-eclampsia? $\mathrm{Ob}-$ stet Gynecol. 2004;104(2):238-42.

31. Suy A, Martinez E, Coll O, Lonca M, Palacio $M$, de Lazzari E, et al. Increased risk of preeclampsia and fetal death in HIV-infected pregnant women receiving highly active antiretroviral therapy. AIDS. 2006;20(1):59-66.

32. Merchant AT, Msamanga G, Villamor E, Saathoff E, O'Brien M, Hertzmark E, et al. Multivitamin supplementation of HIVpositive women during pregnancy reduces hypertension. J Nutr. 2005;135(7):1776-81.

33. Nicholas SW, Bateman DA, Ng SK, Dedyo T, Heagarty MC. Maternal-newborn human immunodeficiency virus infection in Harlem. Arch Pediatr Adolesc Med. 1994;148(8):813-9.

34. Read JS. Preventing mother to child transmission of HIV: the role of caesarean section. Sex Transm Infect. 2000;76(4):231-2.

35. Human Rights Watch. A test of inequality: discrimination against women living with HIV in the Dominican Republic. New York: HRW ; 2004 [cited 2009 Feb 27]. Available from: www.hrw.org/sites/default/files/reports/ dr0704.pdf.

Manuscript received on 7 August 2008. Revised version accepted for publication on 27 April 2009. 
RESUMEN Objetivos. Fortalecer el programa de prevención de la transmisión de la infección por el VIH madre-hijo (PPTIMH) en la provincia de La Romana (LR), mediante la estimación de la prevalencia y la identificación de las características asociadas con esta infección en las mujeres parturientas.

Infección por el VIH en parturientas y prevención de la transmisión madre-hijo en La Romana, República Dominicana, 2002-2006

Métodos. Se tomaron muestras de sangre del cordón umbilical en siete puntos de atención obstétrica, que concentran más de $95 \%$ de los partos de LR, durante las cuatro fases de estudio (piloto, piloto extendido, estudio completo y monitoreo del PPTIMH) entre el 2 de agosto de 2002 y el 30 de septiembre de 2006. Los resultados se enlazaron con los datos extraídos de los registros de parto.

Resultados. La seroprevalencia al VIH fue de 2,6\% (263/10 040 general; 114/4 452 en la fase de estudio completo; intervalo de confianza de $95 \%: 2,1 \%$ a 3,1\%). La mayoría de las parturientas infectadas eran dominicanas $(68,9 \%)$ y de zonas urbanas $(64,0 \%)$. No obstante, la prevalencia fue mayor en las haitianas $(3,7 \%)$ que en las dominicanas $(2,3 \% ; P<0,001)$ —especialmente en las de 21 a 25 años $(5,2 \%$ frente a $2,3 \%$; $P<0,001)$ - y de bateyes y zonas rurales y periurbanas con respecto a las de zonas urbanas $(3,4 \%$ frente a $2,3 \% ; P=0,003)$. La prevalencia de VIH se asoció con actividad sexual profesional (aunque solamente 0,4\% manifestó realizarlo) y embarazos previos. Según el análisis de regresión logística, ser profesional del sexo, haitiana y haber tenido algún embarazo previo se asociaron independientemente con la infección por el VIH. Los partos por cesárea fueron más frecuentes en las seropositivas al VIH, y aumentaron en el último año del estudio; no obstante, la mayoría de los partos de las mujeres seropositivas fueron vaginales $(57,5 \%)$.

Conclusiones. La prevalencia de la infección por el VIH en las parturientas de LR fue mayor que la estimada para la República Dominicana $(0,8-1,0 \%)$ y, en contraste con estudios anteriores, afectó principalmente a las residentes en zonas urbanas. La prevalencia de esta infección en las parturientas haitianas de LR fue mayor que en las dominicanas y las que asistieron a clínicas prenatales en Haití $(3,1 \%)$. Se necesitan intervenciones y PPTIMH dirigidos y consistentes.

Palabras clave Infecciones por VIH; transmisión vertical de enfermedad infecciosa; República Dominicana.

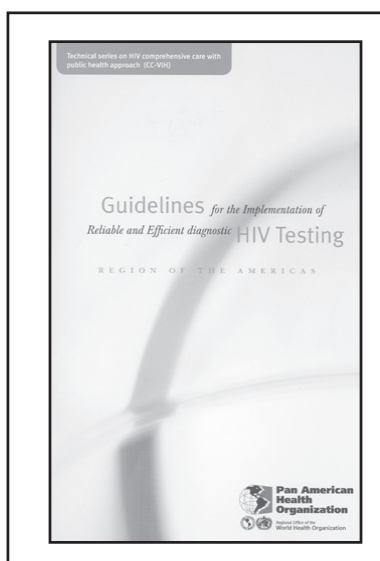

$2008 \cdot$ vi 48 pp. ISBN 9789275129043

This publication is available in electronic format at: http://www.paho.org

\section{Guidelines for the Implementation of Reliable and Efficient Diagnostic HIV Testing}

Testing and counseling for human immunodeficiency viurs (HIV) is now recognized as a priority in national HIV programs because it is the gateway to HIV/AIDS prevention, care, treatment, and support interventions. These guidelines describe a process for implementing government approved, same-visit HIV testing in the Region of the Americas.

These guidelines aim to help countries to expand testing and counseling services by taking advantage of opportunities presented during encounters between health care providers and the public. They describe the actions that need to be taken to deliver HIV testing in VCT settings (clientinitiated testing) and in clinical settings (provider-initiated testing). This document emphasizes approaches that are most likely to have a broad public health impact while focusing on the implementation of reliable and cost-efficient HIV testing in existing health care settings. 